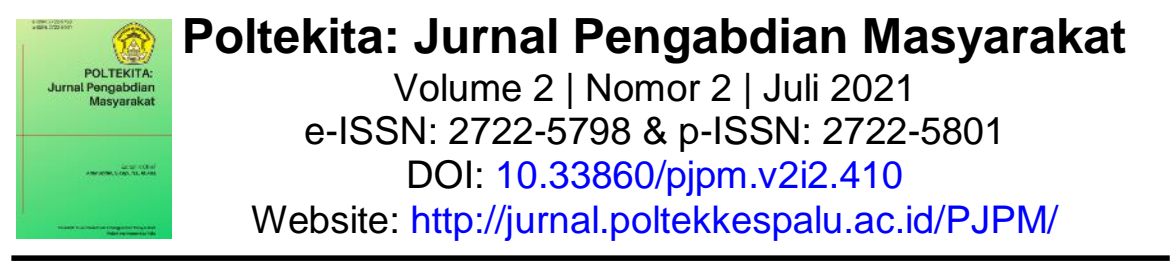

\title{
Sosialisasi Gerakan Masyarakat Sehat dan Pencegahan Stunting di Pondok Pesantren Husnayain
}

\author{
Nasrul $\square$, Fahmi Hafid (D), Lisnawati, Amsal, Masudin, Sri Musriniawati Hasan, Wijianto \\ Poltekkes Kemenkes Palu \\ $\triangle$ Email Korespondensi: nasrulsahe@gmail.com
}

\section{Article history:}

Received: 10-04-2021

Accepted: 02-08-2021

Published: 03-08-2021

\section{Kata Kunci:}

Germas; Stunting; Pesantren.

\section{Keywords:}

Health Society; Stunting; Boarding of School.

\begin{abstract}
ABSTRAK
Keberhasilan gerakan masyarakat sehat tidak terlepas dari kerjasama lintas sektor. Salah satunya dengan Lembaga Pendidikan keagamaan seperti pesantren. Pesantren dapat menjadi fondasi yang kuat bagi penggalakan gerakan masyarakat hidup sehat terutama bagi santri dan pengurusnya. Tujuan pengabdian masyarakat ini adalah terlaksananya kegiatan Sosialisasi Pesantren dan Santri Sehat Pesantren Husnayain Kota Palu. Metode pelaksanaan dengan Sosialisasi Pesantren dan Santri Sehat kepada 20 santri dan santriwati serta pengurus pesantren. Pelaksanaan pada tanggal 8-10 Februari 2021 di Pondok Pesantren Husnayain Kelurahan Silae Kecamatan Ulujadi Kota Palu Sulawesi Tengah. Hasil yang diperoleh dari kegiatan sosialisasi ini adalah terjalinnya kerjasama antara Poltekkes Kemenkes Palu dengan Pesantren Husnayain dalam rangka pembentukan Pos Kesehatan Pesantren (Poskestren) dan pembinaan pesantren dan santri sehat di Kota Palu.
\end{abstract}

\begin{abstract}
The success of the healthy society movement cannot be separated from cross-sector cooperation. One of them is with religious education institutions such as Islamic Boarding School. Islamic Boarding School can be a strong foundation for promoting a healthy life community movement, especially for students and their administrators. The aim of this community service is to carry out the Socialization of Islamic Boarding Schools and Healthy Santri Husnayain Islamic Boarding School in Palu City. The method of implementation is the socialization of Islamic boarding schools and healthy Student to 20 perseon as well as boarding school administrators. The event will be held on 11-12 February 2021 at the Husnayain Islamic Boarding School, Silae Village, Ulujadi District, Palu City, Central of Sulawesi. The results obtained from this outreach activity were the establishment of cooperation between the Health Polytechnic of the Ministry of Health in Palu and the Husnayain Islamic Boarding School in the context of establishing a Pesantren Health Post (Poskestren) and fostering healthy Islamic boarding schools and Student in Palu City.
\end{abstract}




\section{PENDAHULUAN}

Sosialisasi gerakan masyarakat sehat (GERMAS) memiliki kepedulian akan investasi gizi menuju generasi yang berkualitas dan berdaya saing. GERMAS dicirikan antara lain oleh penekanan yang kuat pada kerjasama multisektor, keseimbangan masyarakat antara keluarga dan individu, serta pemberdayaan masyarakat (Darman Saputra, 2019). Upaya GERMAS dan Stunting menjadi tantangan kesehatan masyarakat di Indonesia. Angka stunting di Indonesia $>20 \%$. Stunting menjadi isu prioritas nasional yang harus diupayakan program pencegahannya di berbagai sektor termasuk di Pesantren. Pondok Pesantren telah menjadi salah satu promosi kesehatan yang potensial dalam upaya pencegahan stunting khususnya di usia produktif (Qomaruddin, Siswantara, \& Muthmainnah, 2020). Pondok pesantren adalah lembaga pendidikan Islam yang unik, tertua dan terus berkembang. Sejak puluhan tahun silam, pesantren telah mencatatkan kiprahnya untuk turut membangun Bangsa Indonesia. Oleh karena peran strategisnya itulah, pondok pesantren dapat menjadi fondasi yang kuat bagi penggalakan gerakan masyarakat hidup sehat dan pencegahan stunting. Penting bagi santri untuk mulai mengenal pola hidup terutama pola makan yang sehat sedari dini (Sofia \& Susilo, 2020). Pesantren adalah tempat membangun karakter yang efektif dan tempat untuk mendapatkan banyak nilai humanis disamping ilmu ilmu agama Islam, hingga menjadi wadah belajar untuk egaliter, persamaan nilai setiap orang di depan Tuhan dan persamaan derajat antara sesama manusia. Menjaga kesehatan melalui pola hidup dan pola makan yang baik merupakan bentuk kesyukuran tertinggi atas karunia kehidupan dari Allah SWT. Namun dalam pelaksanaannya ternyata santri telah terbiasa makan bersama dalam satu nampan dan tidur beralaskan tikar di ruangan yang sempit tanpa memandang status sosial (Sofia \& Susilo, 2020).

Pesantren sehat bertujuan meningkatkan pengetahuan dan kesadaran akan pentingnya kesehatan, berkaitan dengan usia para santri dan juga isu-isu kesehatan prioritas nasional seperti Germas, eliminasi TBC, cegah stunting dan peningkatan cakupan imunisasi di kalangan masyarakat pesantren. Kegiatannya diselaraskan dengan agenda bersama Kementerian Kesehatan seperti pembinaan kesehatan lingkungan pondok pesantren, orientasi santri penggerak GERMAS, kampanye Isi Piringku, eliminasi TBC, penerapan perilaku hidup bersih dan sehat, tidak merokok, cuci tangan pakai sabun serta aktivitas fisik dengan menggunakan metode yang dikembangkan bersama Kementerian Kesehatan (Supit, 2019).

Beberapa contoh contoh kegiatan yang terkait dengan GERMAS dan pencegahan stunting yang telah dilakukan oleh pesantren adalah kegiatan Pusat Muslimat Nahdlatul Ulama. sosialiasi pencegahan stunting dengan kerjasama Dinas Kesehatan seperti kebun sehat (Fathoni \& Muchlishon, 2019a). Kegiatan lainnya, Pimpinan pesantren juga menindaklanjuti program gerakan masyarakat hidup sehat dan pencegahan stunting dengan membentuk laskar. Laskar Germas dan pencegahan stunting ini bekerja setelah melalui persiapan, orientasi, dan mobilisasi yang dilakukan PP Muslimat NU (Fathoni \& Muchlishon, 2019b). Kementerian Kesehatan meluncurkan program Peningkatan Kualitas Kesehatan Lingkungan di Pesantren. Program tersebut bertujuan untuk meningkatkan perilaku hidup sehat termasuk pencegahan penularan Covid-19 di pesantren. Penyakit yang biasa ditemukan di pondok pesantren berupa penyakit kulit, Diare, DBD, Malaria, ISPA, TBC. Yang menjadi faktor risiko di pesantren adalah masalah sanitasi, ruangan dan bangunan, serta perilaku masyarakat di pesantren (Istifaiyah, 2019). Harapannya pesantren dapat 
berperan serta dalam memperbaiki kesehatan lingkungannya. Karena kalau santri sehat akan berprestasi dan akan menjadi agent of change di keluarga maupun di masyarakat. Pelaksanaan perilaku hidup bersih dan sehat pada santri di beberapa Pondok Pesantren telah banyak dilakukan diberbagai daerah dan hasilnya telah sesuai yang diharapkan, seperti yang dilakukan oleh (Afriani, Massuhartono, \& Kusnadi, 2020; Damayanti, 2020; Dewi, 2020; Eka noveyani, Caesarina Novi Marchianti, \& Wulandari, 2020; Hidayat, Rohyana, Afif, \& Rahmat, 2021; Istifaiyah, 2019; Mastur, 2020; Nadrati, Wijayanto, \& Musniati, 2019; Purwanto, 2020; Qomaruddin et al., 2020; Tobroni \& Habibi, 2020).

Kerjasama lainnya antara Kementerian Agama, ormas Islam dengan kementerian kesehatan adalah penyelenggaraan peringatan Hari Santri 2020 dengan tema 'Santri Sehat Indonesia Kuat' pada 1 Oktober 2020. Peringatan Hari Santri tahun ini dilakukan dengan menerapkan protokol kesehatan untuk mencegah penularan dan penyebaran Covid-19. Peringatan hari santri disesuaikan dengan kondisi pandemi Covid-19. Dilakukan secara virtual dengan berbagai kegiatan dan lomba. Kegiatan seminar dilakukan virtual untuk menjaga kesehatan para santri dan juga para pengasuh pondok pesantren (Permana \& Hafil, 2020).

Salah satu kegiatan sosialisasi pesantren dan santri sehat pada tahun 2019 (https://www.youtube.com/watch?v=0IM71P6Ani4). Kegiatan ini merupakan kegiatan kerjasama Kementrian Kesehatan Republik Indonesia dengan pimpinan pusat persatuan islam. Pembentukan dan pelatihan Kader Santri Sehat juga diharapkan mampu menjadi salah satu upaya meningkatkan lifeskill hidup sehat bagi santri untuk hidup sehat secara mandiri sekaligus menjaga kestabilan kualitas lingkungan sehat di pesantren yang akan dibentuk (Rif'ah, 2019). Kegiatan lainnya terkait dengan Pesantren Sehat, Santri Kuat: https://www.youtube.com/watch?v=m5_Hvwl3sPg.

Khusus untuk kegiatan pengabdian di Sulawesi Tengah oleh Poltekkes Kemenkes Palu salah satunya adalah sosialisasi germas dan pencegahan stunting di Pondok Pesantren Husnayain. Pesantren ini berlokasi di Silae Kota Palu Sulawesi Tengah dan memiliki banyak santri. Dengan latar belakang tersebut maka tujuan dari kegiatan pengabdian masyarakat ini adalah terlaksana kegiatan sosialisasi gerakan masyarakat sehat dan pencegahan stunting di pondok Pesantren Husnayain Kelurahan Silae Kecamatan Ulujadi Kota Palu.

\section{METODE}

Metode pelaksanaan pengabdian masyarakat dosen Poltekkes Kemenkes Palu dengan penyuluhan dan sosialisasi gerakan masyarakat sehat dan pencegahan stunting di pondok Pesantren Husnayain Kelurahan Silae Kecamatan Ulujadi Kota Palu. Pelaksanaan pada tanggal 8-10 Februari 2021, khalayak sasaran adalah Pimpinan dan Pengelola Pesantren, Uztad dan Santri Pondok Pesantren Husnayain Kelurahan Silae Kecamatan Ulujadi Kota Palu Propinsi Sulawesi Tengah. Tujuan dari kegiatan pengabdian masyarakat Pondok Pesantren Husnayain Kelurahan Silae Kecamatan Ulujadi Kota Palu Sulawesi Tengah adalah untuk meningkatkan perhatian pimpinan yayasan terkait kesehatan pesantren dan santri dan memberikan contoh cara mengukur tinggi badan dan berat badan santri.Pelaksanaan dan pelaporan kegiatan berpedoman pada Pedoman Pengabdian Masyarakat di Politeknik Kesehatan Kementerian Kesehatan (Widagdo et al., 2018). 


\section{HASIL DAN PEMBAHASAN}

Hasil yang diperoleh dari kegiatan sosialisasi ini adalah terjalinnya kerjasama antara Poltekkes Kemenkes Palu dengan Pesantren Husnayain dalam rangka pembentukan Pos Kesehatan Pesantren (Poskestren) dan pembinaan pesantren dan santri sehat di Kota Palu. Hasil kegiatan pengabdian ini menunjukkan ketercapaian tujuan pelaksanaan pengabdian (Emiyanti, Rahfiludin, \& Winarni, 2017; Kementerian Kesehatan R.I, 2014). 1) Pembekalan atau alih teknologi; yaitu penyadaran dengan memberikan informasi dan keterampilan pada penghuni pondok pesantren tentang dasar-dasar, manfaat, dan urgensi PHBS komunitas di lingkungan pondok pesantren; 2) Pendampingan; yaitu melalui pendampingan terhadap pondok pesantren dalam membentuk Poskestren; 3) Pelatihan manajemen dan pembentukan Kader Santri Sehat; yaitu memberikan pengetahuan tentang pengelolaan dan pembangunan relasi kerja untuk Poskestren, serta melakukan pelatihan bagi Kader Santri Sehat sebagai investasi keberlanjutan program Poskestren yang telah didirikan.

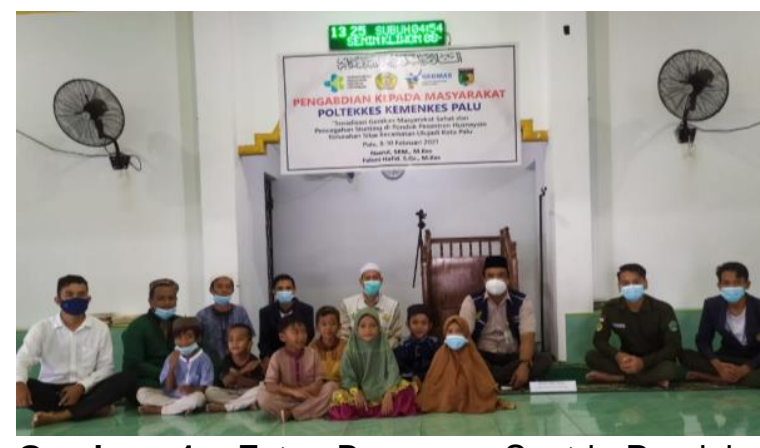

Gambar 1: Foto Bersama Santri Pondok Pesantren Husnayain dan Pelaksana Pengabdian Masyarakat di Kelurahan Silae Kecamatan Ulujadi Kota Palu

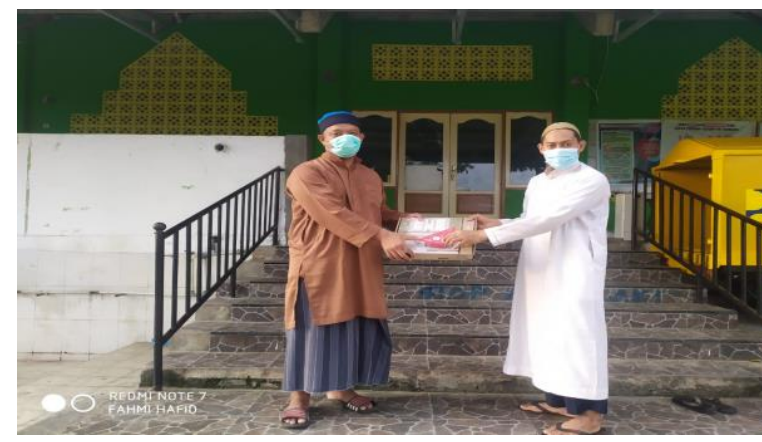

Gambar 3: Penyerahan Timbangan Berat Badan dan Mikrotoice oleh Fahmi Hafid Kepada Uztad Ali Firdaus Pimpinan Pesantren Husnayain Kelurahan Silae Kecamatan Ulujadi Kota Palu.

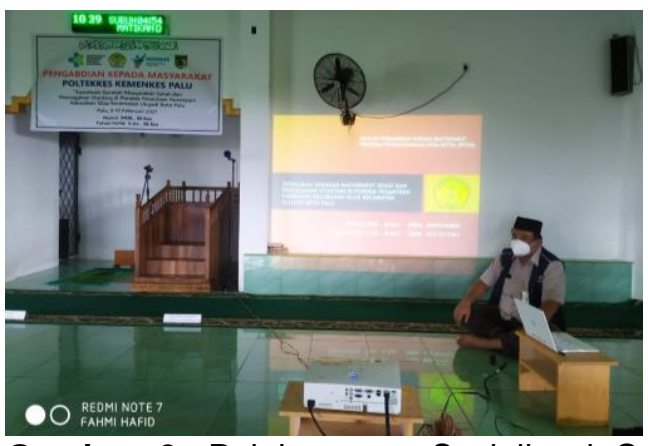

Gambar 2: Pelaksanaan Sosialisasi Sosialisasi Gerakan Masyarakat Sehat dan Pencegahan Stunting di Pondok Pesantren Husnayain Kelurahan Silae Kecamatan Ulujadi Kota Palu oleh Nasrul, SKM., M.Kes

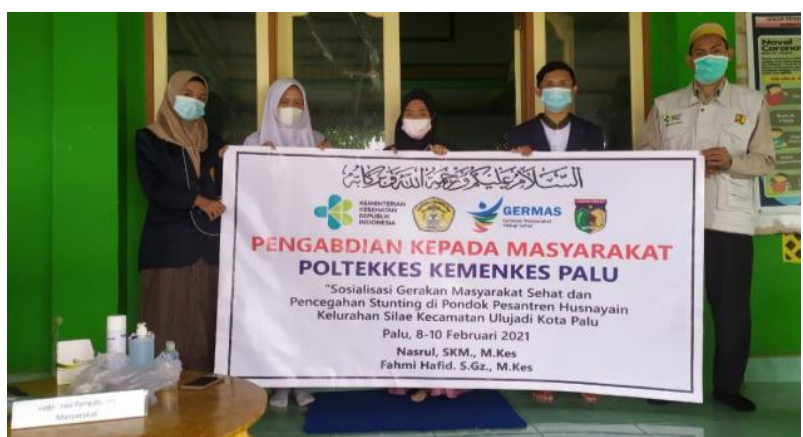

Gambar 4: Pelaksanaan Sosialisasi dan Foto Bersama Santri Pondok Pesantren Husnayain dan Mahasiswa Poltekkes Kemenkes Palu

Adanya partisipasi dari pihak Pondok Pesantren Husnayain yang merupakan mitra dari kegiatan ini dilakukan mulai tahap persiapan hingga pengelolaan Poskestren yang terbentuk. Partisipasi mitra dievaluasi pada setiap kegiatan, sehingga diharapkan pada saat akhir kegiatan, keberlanjutan program dapat tetap berjalan. Hasil evaluasi kegiatan inilah yang diharapkan nantinya akan menjadi pengabdian yang akan datang, 
sehingga program ini dapat terus berlanjut dan dapat memenuhi kebutuhan para santri dalam hal peningkatan derajat kesehatannya. Melakukan sosialisasi mengenai pentingnya pemberian gizi seimbang demi mewujudkan generasi berkualitas dan berdaya saing. Memberikan sosialisasi untuk meningkatkan pemahaman calon ibu dan ibu muda mengenai pemberian ASI Ekslusif serta pemenuhan hak anak.

Kegiatan ini memilih sasaran santri dan pimpinan pesantren dikarenakan pengembangan dan pencegahan adanya penyakit stunting tidak hanya melalui penyuluhan dan ceramah melalui tenaga kesehatan. Pengembangan karakter mulai dari dini yaitu remaja yang menuju pernikahan dapat diacu sebagai target utama dalam pengabdian masyarakat ini dalam pencegahan adanya stunting. Tidak hanya berlalu untuk pribadi apabila memiliki anak dan dapat mencegah stunting namun dengan adanya kader dakwah sehat ini dapat disalurkan dan menjadi kader bagi orang lain melalui kegiatan ini. Santri dan pimpinan pesantren akan diberikan pengetahuan dan ilmu mengenai tugas apa saja sebagai kader dakwah sehat, tujuannya dan kedepannya bagaimana. Selain itu tujuan utama sebagai pencegahan adanya stunting, maka dari itu santri dan pimpinan pesantren akan diberikan pengetahuan dan ilmu mengenai stunting juga. Stunting merupakan penyakit yang sudah menjadi prioritas utama kesehatan masyarakat Memberikannya pengetahuan dan pemahaman dengan lebih mengutamakan pada kompetensi kader pada didesa tersebut sebagai tombak utama dalam mendeteksi dini terjadinya stunting. Hal itu sama dengan sosialisasi yang dilakukan pada pengabdian masyarakat ini, dengan mengutamakan pada santri dan pimpinan pesantren pada pondok pesantren yang bertujuan untuk menyalurkan ilmu tersebut baik dalam bentuk dakwah ataupun melalui kegiatan islami. Karena Indonesia lebih dominan beragama Islam dan memiliki banyak kajian maka dari itu mencari cara untuk menyalurkan dan mengembangkan pencegahan stunting dengan menjadikan kader dakwah sehat ini merupakan salah satu jalan keluar terjadinya stunting pada anak (Qomaruddin et al., 2020). Sosialisasi Gerakan Masyarakat Sehat di Pondok Pesantren Husnayain Kota Palu dapat di lihat pada link Youtube: https://www.youtube.com/watch?v=BfLj8JNwhll

\section{SIMPULAN DAN SARAN}

Kegiatan sosialisasi Pesantren dan Santri Sehat di Pondok Pesantren Husnayain Kelurahan Silae Kecamatan Ulujadi Kota Palu Sulawesi Tengah menghasilkan kerjasama antara Poltekkes Kemenkes Palu dengan Pesantren Husnayain dalam bentuk Pos kesehatan pesantren dan pembinaan pesantren dan santri sehat di Kota Palu. Meningkatkan perhatian pimpinan pesantren terkait kesehatan pesantren dan santri. Memberikan contoh cara mengukur tinggi badan dan berat badan santri.

Diharapkan kegiatan ini dapat berlanjut dengan kegiatan pendampingan pesantren serta santri sehat, Pelatihan manajemen dan pembentukan Kader Santri Sehat; meningkatkan partisipasi mitra mulai tahap persiapan hingga pengelolaan Poskestren yang telah terbentuk. Partisipasi mitra akan dievaluasi pada setiap kegiatan, sehingga diharapkan pada saat akhir kegiatan, keberlanjutan program dapat tetap berjalan.

\section{DAFTAR PUSTAKA}

Afriani, D., Massuhartono, M., \& Kusnadi, E. (2020). Peran Komunitas Gerakan Pesantren Sehat Jambi Dalam Meningkatkan Pengetahuan Kesehatan Mental Santri di Pondok Pesantren Daaru Attauhiid. UIN Jambi. Retrieved from 
http://repository.uinjambi.ac.id/id/eprint/4738

Damayanti, A. Y. (2020). Perilaku hidup bersih dan sehat (PHBS) dan status gizi remaja di pondok pesantren. Darussalam Nutrition Journal. 4(2). 143-150 https://ejournal.unida.gontor.ac.id/index.php/nutrition/article/view/4850

Darman Saputra. (2019). Investasi gizi sebagai upaya menciptakan Germas menuju GENERASI EMAS (Generasi Berkualitas dan Berdaya Saing) 2045 Kecamatan Gerunggang Kota Pangkalpinang. Prosiding Seminar Hukum dan Publikasi Nasional (Serumpun) I 2019 (Vol. 1 , pp. http://prosiding.fh.ubb.ac.id/index.php/prosiding-serumpun/article/view/40/33

Dewi, M. (2020). Pengelolaan Makanan Sehat di Pondok Pesantren Guna Meningkatkan Kesehatan Reproduksi Remaja. Warta Pengabdian. https://jurnal.unej.ac.id/index.php/WRTP/article/view/17567

Eka noveyani, A., Caesarina Novi Marchianti, A., \& Wulandari, P. (2020). Hygiene Sanitasi Lingkungan dalam Potensi Pembentukan Kader Sehat Mandiri Pesantren Nuris Jember. Journal of Health Sciences, https://journal2.unusa.ac.id/index.php/JHS/article/view/1484

Emiyanti, Rahfiludin, M. Z., \& Winarni, S. (2017). Analisis Faktor yang Berhubungan dengan Keikutsertaan Kelas Ibu Hamil Januari-Juli Tahun 2017 (Studi di Kecamatan Muara Tembesi Kabupaten Batang Hari Provinsi Jambi). Jurnal Kesehatan Masyarakat (eJournal), $5(4)$, 801-811. https://ejournal3.undip.ac.id/index.php/jkm/article/view/18781/17861

Fathoni, A., \& Muchlishon. (2019a). Muslimat NU Dorong Pengadaan Kebun Sehat di Pesantren-pesantren. Nu Online. Retrieved October 5, 2020, from https://www.nu.or.id/post/read/110141/muslimat-nu-dorong-pengadaan-kebun-sehat-dipesantren-pesantren

Fathoni, A., \& Muchlishon. (2019b). Muslimat NU Perkuat Laskar Germas dan Pencegahan Stunting. NU Online. Retrieved October 5, 2020, from https://www.nu.or.id/post/read/110925/muslimat-nu-perkuat-laskar-germas-danpencegahan-stunting

Hidayat, C., Rohyana, A., Afif, U. M., \& Rahmat, A. A. (2021). Aktivitas Edukasi Penanaman Perilaku Hidup Bersih dan Sehat (PHBS) di Lingkungan Pondok Pesantren. BERNAS: Jurnal Pengabdian Masyarakat, 2(1), 77-81. ejournal.unma.ac.id. Retrieved from https://ejournal.unma.ac.id/index.php/bernas/article/view/623

Istifaiyah, A. (2019). Hubungan Ventilasi dan Perilaku Hidup Bersih dan Sehat (PHBS) dengan Kejadian Penyakit ISPA (Studi Pada Santri Di Pondok Pesantren Amanatul Ummah Surabaya). repository.unusa.ac.id. Retrieved from http://repository.unusa.ac.id/5456/

Kementerian Kesehatan R.I. (2014). Pedoman Pelaksanaan Kelas Ibu Hamil. Jakarta: Direktorat Jenderal Bina Gizi dan KIA.

Mastur, A. (2020). Penataan Pedagang Kaki Lima untuk Mewujudkan Prilaku Hidup Bersih dan Sehat (PHBS) Pondok Pesantren Assalafi AI Fithrah Surabaya. TARBAWI. 8(2). 137151. http://ejournal.kopertais4.or.id/susi/index.php/tarbawi/article/view/3069

Nadrati, B., Wijayanto, W. P., \& Musniati, M. (2019). Gambaran Perilaku Hidup Bersih dan Sehat (PHBS) Santri di Pondok Pesantren Ad Diinul Qoyyim Lombok Barat. Holistik Jurnal Kesehatan, 13(1), 1-6. http://www.ejurnalmalahayati.ac.id/index.php/holistik/article/view/1126

Permana, F. E., \& Hafil, M. (2020). Tema Hari Santri 2020, Santri Sehat Indonesia Kuat. https://republika.co.id/. Retrieved October 5, 2020, from https://republika.co.id/berita/qhid17430/tema-hari-santri-2020-santri-sehat-indonesiakuat

Purwanto, R. E. (2020). Hubungan sanitasi lingkungan dan perilaku hidup bersih dan sehat dengan kejadian scabies pada remaja di Pondok Pesantren Al-Mizan Kec. Lamongan Kab. Lamongan. repository.umla.ac.id. Retrieved from http://www.repository.umla.ac.id/276/ 
Qomaruddin, M. B., Siswantara, P., \& Muthmainnah, R. D. R. (2020). Blended Learning Kader Dakwah Sehat Dalam Upaya Pencegahan Stunting Sebagai Aplikasi Adaptasi Kebiasaan Baru Di Pondok Pesantren. Semnas.Poltekkesdepkes-Sby.Ac.ld (pp. 1-5). Surabaya: Poltekkes Kemenkes Surabaya. Retrieved from http://semnas.poltekkesdepkessby.ac.id/index.php/2020/article/view/170

Rif'ah, E. N. (2019). Pemberdayaan Pusat Kesehatan Pesantren (Poskestren) Untuk Meningkatkan Perilaku Hidup Bersih Dan Sehat. Warta Pengabdian, 13(3), 96-105. https://jurnal.unej.ac.id/index.php/WRTP/article/view/11862

Sofia, H., \& Susilo, T. (2020). Pesantren dan awal gerakan masyarakat hidup sehat. https://www.antaranews.com/. Retrieved October 5, 2020, from https://www.antaranews.com/berita/1763441/pesantren-dan-awal-gerakan-masyarakathidup-sehat

Supit, V. (2019). Pesantren Sehat, Upaya Kemenkes Mengedukasi dan Mendorong Penerapan Hidup Sehat. infonawacita.com. Retrieved October 5, 2020, from https://infonawacita.com/pesantren-sehat-upaya-kemenkes-mengedukasi-danmendorong-penerapan-hidup-sehat/

Tobroni, M. I., \& Habibi, W. (2020). Pendampingan Progam Membangun Kemandirian Santri Pondok Pesantren Darussalam Sumbersari Melalui Pembiasaan Perilaku Hidup Bersih dan Sehat. Jurnal Pengabdian kepada Masyarakat. 1(1). 283-296 http://ejournal.iaifa.ac.id/index.php/JPMD/article/view/221

Widagdo, W., Warastuti, R., Jauhari, A., Ngadiarti, I., Supartini, Y., Jupriyono, Santoso, S., et al. (2018). Pedoman Pengabdian Masyarakat di Politeknik Kesehatan Kementerian Kesehatan. (T. Nurwati, Y. Widyaningsih, \& Y. Yojana, Eds.) (1st ed.). Jakarta: Pusat Pendidikan SDM Kesehatan. 